\title{
A TIFICAÇÃO DO CRIME DE ASSÉDIO SEXUAL SOB A ÓTICA CONSTITUCIONAL
}

\author{
Tarsis Barreto OLIVEIRA*
}

\begin{abstract}
*Doutor em Direito Público pela UFBA. Mestre em Direito Econômico pela UFBA. Professor Adjunto de Direito Penal da Universidade Federal do Tocantins. Coordenador e Professor do Curso de Mestrado em Prestação Jurisdicional e Direitos Humanos da UFT. Coordenador e Professor do Curso de Especialização em Ciências Criminais da UFT. Editor Científico da Revista de Direito da Escola Superior de Magistratura Tocantinense. Editor Assistente da Revista Jurídica da Defensoria Pública do Tocantins. Parecerista da Revista Guia do Estudante para Cursos de Direito. Parecerista da Revista Jurídica da Presidência da República. Palestrante a autor de obras jurídicas.
\end{abstract}

\section{Recebido em: 30/05/2014 - Aprovado em: 19/09/2014 - Disponibilizado em: 15/12/2014}

RESUMO: Esta pesquisa tem como objetivo investigar a existência de limites negativos, previstos na Constituição Federal, à caracterização do crime de assédio sexual, mormente levando em consideração a realidade brasileira, os princípios constitucionais penais, bem como a ratio do dispositivo jurídico-penal erigido no Art. 216-A do Código Penal Brasileiro. Nesta perspectiva, abordam-se ainda considerações de política criminal, bem como aspectos polêmicos do referido tipo, na busca da salvaguarda do bem jurídico tutelado frente às limitações constitucionais.

PALAVRAS-CHAVE: assédio sexual - Constituição - limites negativos - princípios constitucionais.

\section{LA TYPIFICATION DU CRIME DE HARCÈLEMENT SEXUEL AU POINT DE VUE CONSTITUTIONNEL}

RESUMÉ: Cette recherche a le but d'investiguer l'existence des limites négatives prevues dans la Constitucion Fédéral à la caractérisation du crime de harcèlement sexuel, surtout en considerant la réalité brésilienne, les principes constitutionnels, aussi que la ratio du dispositif juridique-pénal érigé dans l'article 216-A du Code Pénal Brésilien. Dans ce contexte, on analyse les considérations de politique criminel, aussi que les aspects controversés de ce crime, dans la recherche de la sauvegarde du bien juridique protegé vers les limitations constitutionnelles.

MOTS-CLÉ: harcèlement sexuel - Constitution - limites négatives - bien juridique - principes constitutionnelles.

\section{INTRODUÇÃO}

A norma penal incriminadora presente no artigo 216-A do Código Penal Brasileiro suscita polêmicas das mais diversas. Para alguns, representou um avanço na medida em que, seguindo uma tendência mundial (iniciada nos Estados Unidos da América), passou-se a coibir de forma mais precisa as práticas abusivas de conotação sexual promovidas por patrões contra seus empregados.

Por outro lado, a instituição do crime de assédio sexual gerou significativas críticas, sobretudo de 
caráter doutrinário, na medida em que a anterior existência de tipos penais tuteladores dos bens jurídicos correlacionados desautorizava e deslegitimava a nova incriminação.

Neste debate, situamos o tema no contexto da proteção constitucional das liberdades e garantias individuais, dando enfoque aos denominados princípios constitucionais penais, por sua natureza e função limitadores da violência punitiva estatal, levada a efeito com a criminalização constante de novas condutas, sobretudo quando faltar-lhes materialidade e substancialidade.

A adequação aos princípios constitucionais-penais afirma-se como o critério para a escolha dos bens jurídicos a serem tutelados pelo legislador infraconstitucional, de modo a criminalizar somente as condutas atentatórias aos bens jurídicos mais relevantes, com substrato e guarida na norma constitucional e nela dimensionados como valores perenes.

No segundo capítulo, faz-se uma análise das críticas ventiladas pela doutrina ao tipo de assédio sexual, bem como são abordados os critérios utilizados pelo legislador na escolha da criminalização da referida conduta.

O terceiro capítulo foca a classificação doutrinária do crime de assédio sexual, a diferenciação entre o assédio sexual e o assédio moral, as elementares do artigo 216-A CP, as hipóteses de exclusão do tipo, o seu objeto jurídico, assim como as repercussões do assédio nos âmbitos civil e trabalhista.

Em seguida, abordam-se dois pontos de especial interesse no crime em estudo, examinando-se a ação penal no crime de assédio sexual, bem como a investigação da hipótese de incidência do crime na relação professor-aluno.

Por fim, no último capítulo, investiga-se o papel dos princípios constitucionais-penais como limite negativo à violência punitiva estatal, caracterizando-se os princípios da legalidade, intervenção mínima, lesividade, adequação social, insignificância e proporcionalidade, perquirindo, neste contexto, a adequação e os limites da criminalização da figura do assédio frente aos contornos da norma constitucional. 
2. CRÍTICAS AO TIPO DE ASSÉDIO SEXUAL

Poucas figuras típicas são tão criticadas quanto a do assédio sexual, introduzido pelo legislador no ano de 2001 em nosso ordenamento. Uma das críticas mais ferrenhas provém de Bitencourt, ao manifestar-se sobre a prática de cópia de "modismos norteamericanos", e regras de conduta que não se adequam à nossa realidade social. $\mathrm{O}$ referido autor critica algumas condutas, e exemplifica o quão destoante representaria, para a nossa realidade social, a adoção de condutas "celebrizadas", pelo que ele chama de nossos colonizadores, tais como "[...]não entrar sozinho no elevador com alguém do sexo oposto; nunca atender uma funcionária em seu gabinete com a porta fechada; o professor não deve atender aluna sozinha em sua sala, etc." (BITTENCOURT, 2008, p. 25-26)

O modismo de que fala Bitencourt revela-se na medida em que o cenário que precedeu a edição do crime de assédio sexual era marcado por grande debate sobre o tema, alimentado por filmes e reportagens, que sugestionavam à sociedade uma necessária intervenção do legislador. O papel da mídia foi, aqui, decisivo. Inegavelmente, ela exerce uma influência poderosa na sociedade, acabando por incitar o legislador à criminalização constante de novas condutas ou, frequentemente, ao aumento da punição dos crimes já existentes. Este papel da mídia é lembrado por Garcia, para quem:

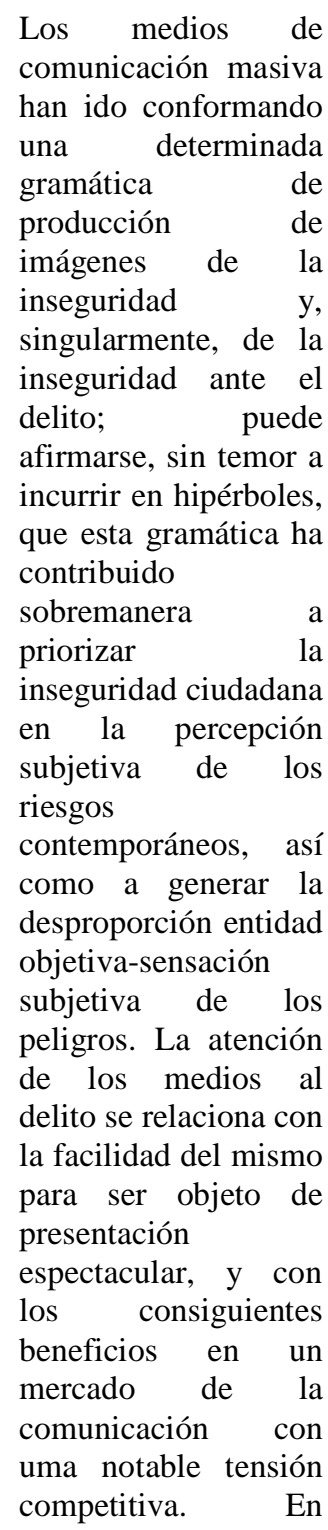




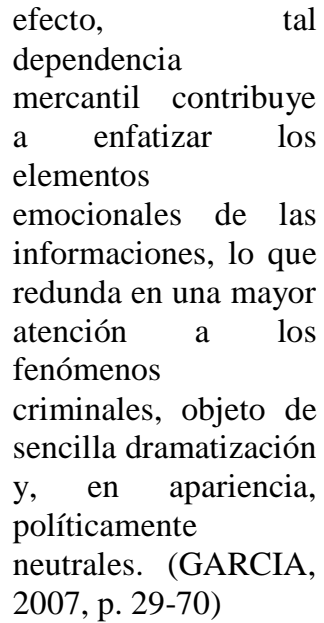

Aponta o referido autor a

força persuasiva dos meios de comunicação, servindo como uma gramática de produção de imagens da insegurança social frente ao crime e aos riscos contemporâneos, o que acaba sendo explorado por um grande mercado da comunicação.

\section{O fato é que a diferença flagrante} de comportamentos, modo de ser e temperamento dos norte-americanos em relação a nós, brasileiros, revela $\mathrm{o}$ contraste de culturas que desautorizaria o nosso legislador a aventurar a introdução desta figura criminosa em nosso ordenamento ${ }^{1}$.

\footnotetext{
${ }^{1}$ Bitencourt reforça ainda o caráter fragmentário e subsidiário do Direito Penal (conforme será trabalhado no capítulo 7), a deslegitimar a incriminação da figura do assédio sexual. Para o autor: "Antes de recorrer ao direito penal devemse esgotar todos os meios extrapenais de controle social. No entanto, os legisladores
}

Desafortunadamente, assim não procedeu o legislador, criando mais um tipo no ordenamento jurídico-penal pátrio, em flagrante contrassenso à tendência descriminalizadora própria ao Direito Penal moderno ${ }^{2}$. Mais ainda, provocou choques e conflitos a partir do momento em que o juízo valorativo atribuído à norma necessitava coadunarse, nas hipóteses de assédio sexual, à realidade de nosso temperamento latino, considerados o nosso modo de ser específico e natureza particular de interrelação.

Ademais, é inegável que transformações profundas se processaram

contemporâneos - tanto de primeiro como de terceiro mundo - têm abusado da criminalização e da penalização, em franca contradição com o princípio em exame, levando ao descrédito não apenas o direito penal mas também a sanção criminal, que acaba perdendo a força intimidativa diante da "inflação legislativa" reinante nos ordenamentos positivados. A criminalização do "assédio sexual" insere-se nesse contexto, alem de, provavelmente, vir a fundamentar muitas denunciações caluniosas, especialmente nas demissões sem justa causa". BITENCOURT, 2008, p. 26-27.

${ }^{2}$ Para Prado, é de se repelir a política adotada pelo legislador brasileiro, que vem inserindo no ordenamento jurídico medidas de natureza penal na tentativa de solucionar problemas sociais, atentando contra princípios fundamentais do Direito Penal, em especial o princípio da intervenção mínima. PRADO, Luiz Régis. Curso de direito penal brasileiro: parte especial, v.3. 4. ed. São Paulo: Revista dos Tribunais, 2006, p. 221. 
ao longo das últimas décadas, marcadas por uma maior frouxidão de costumes, abrandamento das tensões provocadas pelo tema sexo, apelo ao erotismo, acesso mais rápido a conteúdos eróticos e uma maior abertura para o diálogo em todos os ambientes. Todo este contexto deve ser levado em conta pelo legislador no exame das hipóteses fáticas circundantes ao assédio. A propósito, as mudanças no comportamento social relativas ao sexo são inegáveis, como lembram Brents e Sanders, apontando, inclusive, para o próprio crescimento do comércio do sexo, o que não se justificava há algumas décadas:

Academic researchers have pointed out changes in latecapitalism culture and economies that encourage and 'normalize' the growth of sexual commerce. Latecapitalism mass consumption has encouraged a pornographication of culture, a liberalization of sexual attitudes, and more egalitarian attitudes toward intimacy with an element of disposability about relationships if they are not providing full satisfaction.

(BRENTS;
SANDERS, 2010, p. 44)

Este conjunto de transformações influenciou o nosso modo de agir, os nossos próprios usos, fazendo-nos atuar de acordo com as mudanças que se processaram no contexto social. A respeito dos usos, Ortega y Gasset $^{3}$ caracteriza-os como ações que executamos em virtude de uma pressão social, marcadas por uma irracionalidade, já que, ao seguirmos estas convenções, passamos a viver por conta da sociedade, assimilando as ideias e normas por ela determinadas, o que, não obstante, encontra efeito positivo na possibilidade de previsão do comportamento dos indivíduos que não conhecemos, tornando viável a convivência social. (ORTEGA Y GASSET, 1973, p. 48)

No que se refere à realidade brasileira e aos nossos usos sociais, as profundas transformações ocorridas no âmbito cultural, bem como a particular forma de nos inter-relacionarmos não

\footnotetext{
${ }^{3}$ Segundo Ortega y Gasset, os usos são "formas de comportamento humano que o indivíduo adota e cumpre porque, de um modo ou de outro, em uma ou em outra medida, não tem mais remédio. São-lhe impostos pelo seu contorno de convivência: pelos "demais", pela "gente", pela... sociedade". ORTEGA Y GASSET, José. O Homem e a gente: inter-comunicação humana. Trad. J. Carlos Lisboa. 2. ed. Rio de Janeiro: Livro Ibero-Americano, 1973, p. 48.
} 
foram levadas em conta pelo legislador, dando vazão à criação de um tipo descontextualizado e desnecessário. Mesmo no reconhecimento de que existem abusos nas relações de trabalho, é irrefutável que persiste a clara possibilidade de se regulamentar esses excessos por meio de outros ramos do direito, em respeito ao princípio da subsidiariedade.

No âmbito extra penal, o assédio sexual pode gerar a rescisão do contrato de trabalho, conforme previsto na CLT, bem como a rescisão indireta do contrato de trabalho, quando praticada por pessoa em posição de comando ou mesmo na prática por empregador ou preposto da empresa. No caso de rescisão indireta, por condutas deste tipo praticadas por prepostos ou empregadores, há a responsabilização do empregador, respondendo este objetivamente pelos danos causados à vítima, fundada na teoria da culpa resumida por atos de preposto. $^{4}$

\footnotetext{
${ }^{4}$ Tais alegações tem como premissa a literalidade dos art. 482 alínea "b" e 483 alínea "e", ambos da CLT, bem como os art. 932 inciso III e art. 933 do Código Civil Brasileiro. Em seus textos dispõem que:

Art. 482 - Constituem justa causa para rescisão do contrato de trabalho pelo empregador: [...] b) incontinência de conduta ou mau procedimento.
}

Desta forma, verificam-se, em sede de direito trabalhista, bem como no âmbito do direito civil, instrumentos capazes de coibir tais práticas, e quando estas sejam cometidas, pode-se instrumentalizar a reparação do dano cometido sem que, para isso, seja necessária a utilização do meio traumático do poder punitivo viabilizado pelo Direito Penal.

A propósito, a desnecessidade de criminalização da figura do assédio sexual é lembrada por Silva Neto, nos seguintes termos:

E quando nos
insurgimos com
veemênciar contra
todaráritude
fleumática para com o
assédio, não estamos
contraditoriamente
refluindo no que se
refere à afirmação
extratada no início do
item 1; não, apenas
entendemos que a
mera previsão
normativa da conduta

Art. 483 - O empregado poderá considerar rescindido o contrato e pleitear a devida indenização quando: [...] e) praticar o empregador ou seus prepostos, contra ele ou pessoas de sua família, ato lesivo da honra e boa fama.

Art. 932 - São também responsáveis pela reparação civil: [...] III - o empregador ou comitente, por seus empregados, serviçais e prepostos, no exercício do trabalho que lhes competir, ou em razão dele.

Art. 933 - As pessoas indicadas nos incisos I a V do artigo antecedente, ainda que não haja culpa de sua parte, responderão pelos atos praticados pelos terceiros ali referidos. 


\begin{abstract}
como tipo penal específico não resolve o problema, pois bem poderia o legislador deixar que a questão fosse resolvida pelo juiz do trabalho, porquanto é no recinto da relação de emprego que se consuma a prática semelhante. Com isso, profetizamos que poucos serão os casos conduzidos à esfera penal e, ainda assim, menos ainda serão as hipóteses de condenação com base no recém-editado art. 216-A do CP, fundamentalmente à conta da imprecisão semântica e da excessiva largueza do tipo penal. (SILVA NETO, 2002, p. 94)
\end{abstract}

As críticas de cunho doutrinário não cingem apenas à criminalização ${ }^{5}$ da figura do assédio sexual, como também à própria construção da figura típica (norma penal incriminadora). Neste mister, para

\footnotetext{
${ }^{5}$ Sobre esta criminalização, Câmara se posiciona: "Não há dúvidas que o assédio sexual não é fato novo: nasceu com a própria humanidade - caso contrário a própria humanidade não estaria aí. $\mathrm{O}$ Direito se encontra convenientemente aparelhado para que se extirpem os incômodos oriundos da tradicional prática. Para que, então, mais leis se já temos tantas e tantas são que a inaplicabilidade tem sido o destino dessas Leis?! Basta que se dê atenção à existência do fato axiologicamente considerado (e isto deve ser trabalho de doutrinadores) e que sobre ele se desencadeie o contingente normativo, seja trabalhista, seja penal, seja civil de que dispomos, apenas se respeitando a forma de sistema jurídico no qual nos inserimos". CAMARA, Edson de Arruda. Assédio sexual: um problema trabalhista, penal ou cível? In: Revista TRT 6 Região. V. 10, n. 26, ago/dez, 1998, p. 45.
}

Nucci $^{6}$, o tipo do art. 216-A menciona apenas o verbo "constranger", sem qualquer complementação, dando a entender que está incompleto, já que a previsão "com o intuito de obter vantagem ou favorecimento sexual" é apenas elemento subjetivo específico, referindo-se à vontade, mas sem qualquer ligação com a conduta retratada pelo constrangimento. A solução hermenêutica proposta pelo citado autor é a de interpretar que se trata de um constrangimento ilegal específico, que, diferentemente do crime de estupro, não possui os elementos violência ou grave ameaça, caracterizando-se o constrangimento na intenção do agente de forçar a vítima a fazer algo que a lei não manda ou a não fazer o que ela permite, só que ligado a vantagens ou favores sexuais. (NUCCI, 2008, p. 874-875)

Esta é, a propósito, mais uma crítica que se tece à instituição do crime de assédio sexual: a conduta de quem constrangia uma pessoa em um ambiente de trabalho, assediando-a com o intuito de

\footnotetext{
${ }^{6}$ Para Nucci, a construção do tipo não foi bem feita: "Nota-se que o verbo constranger exige um complemento. Constrange-se alguém a alguma coisa." NUCCI, Guilherme de Souza. Código penal comentado. 6. ed. São Paulo: Revista dos Tribunais, 2006, p. 825-826.
} 
obter vantagem ou favorecimento sexual, já poderia enquadrar-se, a depender do caso, no crime de constrangimento ilegal, previsto no Art. 146 do CP. Não obstante, verifica-se atualmente um mecanismo de criminalização constante, a utilizar o Direito Penal como instrumento de força para obter-se resultados esperados, como se este ramo do Direito fosse capaz de resolver todos os problemas da humanidade, e como se todas as condutas imorais (ou, mesmo, ilícitas para outras áreas do Direito) necessitassem, forçosamente, ser criminalizadas.

\section{O CRIME DE ASSÉDIO SEXUAL: ASPECTOS DOUTRINÁRIOS}

O assédio sexual está disposto no Artigo 216-A do Código Penal, com a seguinte descrição típica: "Constranger alguém com o intuito de obter vantagem ou favorecimento sexual, prevalecendo-se o agente da sua condição de superior hierárquico ou ascendência inerentes ao exercício de emprego, cargo ou função", tendo previsto em seu preceito secundário a pena de reclusão de 1 (um) a 2 (dois) anos.
Inicialmente, cumpre salientar que o assédio sexual ${ }^{7}$ se diferencia do chamado assédio moral, também presente no âmbito das relações laborais, mas com claras diferenças. Assédio sexual é crime, enquanto que o assédio moral, não. $\mathrm{O}$ primeiro se caracteriza pela sua conotação de natureza sexual, enquanto que o segundo pelo intuito do empregador em humilhar, denegrir e menosprezar o empregado. Apesar de muita discussão sobre a eventual necessidade de criminalização da conduta do assédio moral, a posição aqui adotada é a de que se deve evitar mais uma criminalização desnecessária no ordenamento jurídicopenal pátrio ${ }^{8}$.

\footnotetext{
${ }^{7}$ Como reporta Santos, inúmeros são os países que têm legislação sobre o tema, criminalizando, a exemplo do Brasil, a figura delituosa do assédio sexual, a exemplo da Argentina (acoso sexual), México (hostigamiento sexual), Estados Unidos (sexual harassment), dentre outros. SANTOS, Aloysio. Assédio sexual nas relações trabalhistas e estatutárias. Rio de Janeiro: Forense, 1999, p. 61-67.

${ }^{8}$ Sobre a diferença entre assédio sexual e assédio moral, Bitencourt discorre: "É uma impropriedade falar em assédio moral, especialmente quando se procuram na legislação alienígena determinadas figuras típicas, como ocorre no caso da França. Eventuais comportamentos moralmente constrangedores encontrarão apoio em outras searas do direito (trabalhista, administrativa, disciplinar), ou mesmo no Direito Penal, em outros tipos, por exemplo, nos arts. 146 ou 147 ou nos crimes contra a honra. Contudo, se se quiser distinguir, no impropriamente denominado "assédio moral" a finalidade da ação criminalizada não é obter "vantagem ou favorecimento moral"
} 
Trata-se a figura do assédio sexual de crime comum, formal, instantâneo 9 (sua consumação se dá em um certo momento), de dano, e cuja tentativa, embora de difícil visualização, é admissível $^{10}$, sendo tal admissibilidade ventilada por se tratar de crime plurissubsistente e, por essa razão, admitir o fracionamento do iter criminis. Quanto ao elemento subjetivo do tipo, este é o dolo, caracterizado pela intenção do agente em obter vantagem ou favorecimento sexual da vítima ${ }^{11}$.

(como ocorre no assédio sexual), mas humilhar, constranger moralmente a vítima, colocá-la em situação vexatória, etc. Mas isso, repetindo, encontra proteção em outros setores do ordenamento jurídico. Quanto menos se falar sobre isso melhor, para não estimular mais uma esdrúxula figura típica. BITENCOURT, 2006, p. 47.

9 Denomina-se aqui "crime instantâneo" para contrapô-lo ao "crime permanente", cuja consumação se protrai no tempo, a exemplo do seqüestro e cárcere privado (art. $148 \mathrm{CP}$ ) ou da extorsão mediante seqüestro (art. $159 \mathrm{CP}$ ).

10 Mirabete reconhece a dificuldade de visualização prática da tentativa de assédio sexual, apontando como exemplo a palavra escrita que não chega ao conhecimento da vítima. MIRABETE, Júlio Fabbrini. Manual de direito penal, v. 2: parte especial: arts. 121 a 234-B do CP. 27. ed. São Paulo: Atlas, 2010, p. 404.

${ }^{11}$ Lembra Carneiro que o delito pode existir ainda que a vantagem ou favorecimento sexual não sejam para o agente, mas para terceira pessoa. CARNEIRO, Yuri. O Novo delito de assédio sexual: a necessidade de uma análise crítica em face do direito penal moderno. In: Revista dos mestrandos em Direito da UFBA: estudos em homenagem ao Professor Josaphat Marinho. JanDez 2001, p. 419.
Nota-se que, apesar de não se tratar de crime habitual ${ }^{12}$ (já que apenas um ato praticado pelo assediador já é suficiente para caracterizar o crime), o assédio sexual é, não obstante, mais perfeitamente visualizado na reiteração da conduta do agente, que, em suas investidas contra a vítima, deseja obter vantagem ou favorecimento sexual, malgrado inequívoco dissentimento desta.

Falamos isso porque não vislumbramos o crime de assédio sexual em certas situações específicas, a exemplo da conduta do chefe que, em um ambiente de trabalho, faz, tão somente, um convite a sua secretária para juntos tomarem um café, ainda que implícita, clara e manifesta a conotação sexual ou a intenção do agente de lograr vantagem sexual. Com efeito, não se compreende como este fato (malgrado pretensa censurabilidade moral), possa, por si só, merecer o enquadramento penal, a admitir o processamento criminal do autor da proposta.

A conduta perquire, para que seja subsumida ao tipo penal, que haja o

\footnotetext{
12 Denomina-se "crime habitual" ao crime cuja consumação requer a prática reiterada da conduta incriminada pelo agente, inadmitindo, portanto, a tentativa.
} 
repúdio da vitima, com inegável constrangimento do sujeito passivo frente a meios coercitivos do autor do fato, que utiliza-se de sua relação de poder para forçar uma relação inadmitida, a priori, pela vítima.

Note-se, no exemplo ventilado, que à funcionária, em vista do convite proposto, não restam senão duas opções, ambas em conformidade com a sua livre manifestação de vontade e sua liberdade de dispor como queira de seu trato íntimo-afetivo e/ou sexual: a de aceitar ou recusar o convite.

Crê-se, até onde se estende a hipótese casuística em apreço, que nenhum ilícito se cometeu, não sendo necessárias razões para justificar, em um estado democrático de direito, que alguém, no exercício do seu jus libertatis, possa ser processado criminalmente apenas por expressar livremente o seu apreço ou desejo de natureza sexual por outra pessoa, ainda que em razão e nas circunstâncias de um ambiente de trabalho. Ora, o desejo de um indivíduo ${ }^{13}$

\footnotetext{
${ }^{13}$ Sobre os desejos humanos, escreve Descartes: "Quando a alma deseja alguma coisa, todo o corpo se torna mais ágil e mais disposto a mover-se do que costuma ser sem isso. Além disso, quando ocorre que o corpo está disposto dessa forma, isso torna os desejos da alma mais fortes e mais
}

por seu semelhante nasce livremente e, mesmo que expresso em ambientes sociais ou laborativos, pode manifestar-se sem que isso precise, a priori, repercutir no âmbito do Direito Penal.

Diferentemente, teríamos a situação em que um chefe, não se conformando com uma inequívoca ${ }^{14}$ recusa da funcionária, pretendesse fazendo-se valer de sua superioridade hierárquica ou ascendência, inerentes ao exercício de emprego, cargo ou função -, envidar esforços tendentes à obtenção de vantagens de natureza sexual com o dissentimento manifesto daquela. Nesta hipótese, visualizaríamos, inegavelmente, o crime de assédio sexual. Neste caso, há, por meio das relações de poder, a interferência desautorizada legalmente em uma instância da vida privada do assediado: a liberdade sexual, que autorizaria a incidência da norma penal incriminadora.

ardentes". DESCARTES, René. As paixões da alma. Trad. Ciro Mioranza. São Paulo: Escala, 2006, p. 87.

${ }^{14}$ Falamos inequívoca para frisarmos a atipicidade da conduta nos casos em que a vítima apenas aparentemente recusa a proposta e/ou investidas do (a) seu (a) chefe, quando, na verdade, comporta-se de maneira indiferente, desavergonhada, estimuladora, debochada, hilária ou despudorada às cantadas e abordagens de seu superior, não manifestando uma objeção clara a um eventual ataque à sua intimidade e dignidade sexual e profissional. 
Observe-se que, em havendo consentimento do (a) empregado (a), não se haverá de falar, em hipótese alguma, de assédio sexual. Requer-se, em igual medida, a análise do comportamento da vítima como condição determinante para a configuração ou não do crime. A este respeito, Silva Neto, com particular clareza, pondera que "Há pessoas tímidas e as mais "atiradas" no que toca à questão sexual; mas há também aquelas que não impõem limites ao modo e ao momento para manifestar o seu desejo ou atração sexual por outrem." (SILVA NETO, 2002, p. 90)

Lembra ainda o referido autor que é indiferente, para a caracterização do tipo, a ocorrência do assédio sexual dentro ou fora da jornada de trabalho, desde que a proposta de relacionamento sexual esteja atrelada ao contrato de trabalho, já que são frequentes as ocorrências de assédio fora do ambiente laborativo. (SILVA NETO, 2002, p. 100)

No que se refere ao objeto jurídico do crime de assédio sexual, Andreucci (2008, p. 294) aponta a tutela da liberdade sexual da vítima, protegendo-se, secundariamente, a honra, a liberdade e a autodeterminação no trabalho. Igualmente, Ishida (2009, p. 381) menciona a liberdade sexual da pessoa como o objeto jurídico tutelado, acrescentando, ainda, a liberdade ao exercício do trabalho. Mirabete (2010, p. 403), por seu turno, estende a proteção da tutela penal, abarcando não apenas a liberdade sexual e a liberdade do exercício do trabalho, mas também a honra e a não discriminação no ambiente de trabalho.

Não obstante, em que pese a pluriofensividade do crime de assédio sexual, entende-se que o seu objeto jurídico primordial é a dignidade sexual de pessoa, e não a sua liberdade sexual, visto que referida expressão se coaduna mais propriamente à mudança terminológica introduzida pela lei 12.015/09, cujo título passou a configurar como crimes contra a dignidade sexual, substituindo a expressão crimes contra $a$ liberdade sexual. Note-se que a dignidade sexual é apenas uma variante ou expressão do princípio da dignidade da pessoa humana ${ }^{15}$, princípio basilar da

\footnotetext{
${ }^{15}$ Lembra Roxin que a dignidade humana "vem sendo recentemente utilizada na Alemanha e também na discussão internacional como um instrumento preferido para legitimar proibições penais". ROXIN, Claus. Estudos de direito penal. Trad. Luís Greco. Rio de Janeiro: Renovar, 2006, p. 39.
} 
Constituição e norteador do sistema jurídico pátrio.

No que se refere ao momento consumativo $^{16}$ do crime, pondera com propriedade Mirabete que este se consuma com $\mathrm{O}$ ato constrangedor, independentemente da efetiva prática do ato de caráter sexual, a exemplo dos beijos, abraços lascivos e toques. Sem dúvida, a satisfação da lascívia do agente do crime de assédio sexual importará, a rigor, no crime de estupro (artigo 213 $\mathrm{CP}$ ), havendo, na hipótese, concurso material de crimes entre os artigos 213 e 216-A do Código Penal.

Registre-se que o assédio sexual, em que pese maior repercussão no campo do Direito Penal, possui, por óbvio, significativos desdobramentos jurídicos no Direito do Trabalho, afinal, é no âmbito da relação de trabalho que se visualiza o ilícito cometido. $\mathrm{O}$ empregado, de acordo com a Consolidação das Leis do Trabalho, é munido de inúmeras garantias, seja no âmbito do direito material como do

\footnotetext{
16 Justamente por esta característica, Mirabete reconhece a dificuldade de visualização prática da tentativa no crime de assédio sexual, apontando, ademais, o exemplo da palavra escrita que não chegou ao conhecimento da vítima. MIRABETE, 2010, p. 404.
}

direito processual trabalhista, a engendrar igualmente consequências de natureza jurídico-laboral para o superior hierárquico que atua de forma afrontosa às garantias do empregado ${ }^{17}$.

Dentre essas consequências que recaem sobre o(a) empregador que assedia sexualmente o(a) empregado(a), está a obrigação de indenização por dano moral. Este é entendido, na visão de Damian e Oliveira (1999, p. 151), como tudo aquilo que molesta gravemente a alma humana, ferindo-lhe gravemente os valores fundamentais inerentes à sua personalidade ou reconhecidos pela sociedade em que está integrado ${ }^{18}$.

A este respeito, não é raro ocorrer que o patrão, por ver-se obstaculizado na satisfação de seus desejos de natureza sexual por recusa da vítima, promova, arbitrariamente, a sua

\footnotetext{
${ }^{17}$ Conforme abordamos no capítulo 2 quando pontuamos as críticas existentes relacionadas a desnecessária tutela penal do assédio sexual.

${ }^{18}$ Para Damian e Oliveira, não há como enumerar exaustivamente as hipóteses de dano moral, podendo evidenciar-se na dor, angústia, sofrimento, tristeza pela ausência de um ente querido falecido, desprestígio, desconsideração social, descrédito à reputação, humilhação pública, devassamento da privacidade, desequilíbrio da normalidade psíquica, traumatismos emocionais, dentre outros. DAMIAN, Sérgio A. S.; OLIVEIRA, Joabet T. de. Assédio sexual: dano e indenização. São Paulo: Edijur, 1999, p. 151.
} 
dispensa do trabalho ${ }^{19}$. Não obstante, como reporta Delgado (2008, p. 1133), o desrespeito às garantias jurídicas estabelecidas em lei tende a tornar nula a dispensa sem justa causa, tendo como consequência a reintegração ao emprego ou, conforme o caso, o pagamento da indenização correlata.

Mesmo entendimento possui Martins (2009, p. 355), para quem o empregador, apesar de possuir o direito potestativo de dispensar o empregado, terá, nesses casos, de arcar com os valores laborais de aviso prévio, $13^{\circ}$ salário proporcional, férias vencidas e proporcionais, saldo de salários, além de ter o empregado direito ao saque do FGTS, indenização de $40 \%$ e direito ao seguro-desemprego.

19 Para Gomes e Gottschalk, "A despedida arbitrariamente decidida pelo empregador, além de ser fonte inesgotável de desemprego, constitui, historicamente, resquício do soberano poder do chefe de empresa, incontrastável e arbitrário. Daí modernamente as legislações exigirem a motivação da despedida em razões de ordem técnica, econômica, financeira, etc., além de submeter o ato da despedida a certas formalidades processuais, como, por exemplo, a comunicação ao empregado dos motivos da despedida, por escrito, e outros procedimentos". GOMES, Orlando; GOTTSCHALK, Elson. Curso de direito do trabalho. 18. Ed. Rio de Janeiro: Forense, 2008, p. 359.
Este conjunto de garantias ${ }^{20}$ tem como corolário o princípio da proteção, visto por Cairo Júnior (2006, p. 50) como “o princípio dos princípios do Direito do Trabalho", constituindo a própria essência do Direito Laboral, sem o qual este domínio do Direito não teria a sua própria autonomia.

Como se vê, o empregado,
exposto que está a inúmeras contingências no âmbito de uma relação laboral, pode ainda estar exposto, pela sua própria condição de hipossuficiência em relação ao empregador (superior hierárquico), a constrangimentos que afrontam a sua dignidade e as suas garantias $^{21}$ em uma relação de trabalho.

Não se afasta ainda a possibilidade da reparação do dano moral

\footnotetext{
${ }^{20}$ No âmbito das garantias ao trabalhador, Cassar relaciona, com propriedade, os princípios gerais constitucionais do trabalho à Magna Carta, mencionando o respeito à dignidade da pessoa humana (art. $1^{\mathbf{0}}$, III CF) e os valores sociais do trabalho e da livre iniciativa (art. $1^{\mathbf{o}}$, IV CF). CASSAR, Vólia Bonfim. Direito do Trabalho. 2. ed. Niterói: Impetus, 2008, p.178.

${ }_{21}$ Nascimento, neste mister, entende como "garantias mínimas do trabalhador" o princípio universal protetivo do Direito do Trabalho, respeitado que é de forma transcendental, já que em todos os países há direitos trabalhistas mínimos, impostos de modo heterônomo e impostergáveis como vantagens fundamentais. NASCIMENTO, Amauri Mascaro. Curso de direito do trabalho: história e teoria geral do direito do trabalho: relações individuais e coletivas do trabalho. 24. ed. São Paulo: Saraiva, 2009, p. 387.
} 
sofrido, em consonância ao direito fundamental estampado no inciso $\mathrm{X}$ do Art. $5^{\circ}$ da $\mathrm{CF} / 88$, que prevê a indenização moral quando o ofendido se vê violado em sua honra. Logo, é possível que seja utilizada a sentença condenatória como título executivo para uma eventual indenização a título de danos morais, no que se conhece como ação civil ex delicto.

Em se tratando de crime de assédio sexual, vê-se que o fato comporta inúmeros desdobramentos jurídicos, visto atingir, além da honra e autodeterminação do trabalhador, também a sua dignidade sexual, o que acaba por repercutir não só no âmbito trabalhista, com a indenização do trabalhador a cargo do assediador ou do empregador; mas também no âmbito administrativo $^{22}$ (se se tratar de relação de cargo ou função pública), civil (com a reparação dos danos contra a honra) e criminal.

\footnotetext{
${ }^{22}$ Conforme trabalharemos adiante, existem precedentes considerando tal prática sujeita as penalidades administrativas da lei 8429/92, mais especificamente em seu art. 11 que diz: Constitui ato de improbidade administrativa que atenta contra os princípios da administração pública qualquer ação ou omissão que viole os deveres de honestidade, imparcialidade, legalidade, e lealdade às instituições...
}

\section{AÇÃO PENAL}

Seguindo a regra geral dos crimes sexuais, a ação penal no crime de assédio sexual é pública condicionada à representação (exceto se se tratar de vítima maior de 14 e menor de 18 anos ou, ainda, em se tratando de vítima vulnerável, nestes casos sendo a ação penal pública incondicionada). Note-se que, no que se refere à ação penal nos crimes sexuais, processou-se uma mudança significativa engendrada pela lei 12.015/09, tendo como mola propulsora o enfrentamento da impunidade nos crimes agora denominados "contra a dignidade sexual $^{23,}$.

Ao se efetuar uma mudança da ação penal privada para pública condicionada à representação, procedeuse a uma alteração na titularidade da ação penal, que agora fica, em quaisquer dos crimes elencados no referido capítulo, nas mãos do Ministério Público, este o

\footnotetext{
${ }^{23}$ Importante frisar que antes da Lei $12.015 / 09$, os crimes contra a dignidade sexual eram, em regra, de Ação Penal de Iniciativa Privada, sendo a exceção (nos casos de abuso de poder familiar, crime praticado com violência real ou qualificado por lesão grave ou morte a ação era Pública Incondicionada, e nos casos de vitima pobre, era a ação Condicionada à Representação), à época ainda era válida a Súmula 608 do STF, hoje já ultrapassada.
} 
competente para oferecer a denúncia em juízo.

Sob o ponto de vista prático, a vítima, com o advento da nova lei, não necessitará mais contratar um advogado ou pleitear assistência judiciária à Defensoria Pública (se hipossuficiente) para fazer valer o seu direito de ver processado criminalmente o autor do crime de assédio sexual, bastando, tão somente, que ofereça Representação, como condição de procedibilidade para o oferecimento da ação penal, ou seja, a simples manifestação de vontade no processo $^{24}$. Incumbirá, portanto, ao Ministério Público, por meio da denúncia, acionar o Estado-juiz, invocando o processamento criminal do autor do fato. Por oportuno, saliente-se que a mudança da ação penal refletiu, nesses casos, na impossibilidade do perdão da vítima, possibilitando, no entanto, a retratação da representação, nos termos do art. 25 do CPP, desde que seja feita antes do momento do oferecimento da denúncia. A decadência da ação penal ainda é possível, desde que não seja manifestada

24 A maioria da doutrina entende que a representação não necessita de formalismos para ser aperfeiçoada, bastando que de qualquer declaração, mesmo nos atos do Inquérito Policial, se retire a certeza da vontade da vítima quanto a persecução penal. a vontade da vítima até 6 meses do acontecido.

Como se frisou, no caso de crime contra maior de 14 e menor de 18 anos, em sendo a ação penal pública incondicionada, caberá ao Ministério Público, obrigatoriamente, oferecer a denúncia, mas, neste caso, independentemente de manifestação de vontade da própria vítima ou de quem quer que seja, podendo o fato ser levado ao conhecimento das autoridades por qualquer do povo, o que acaba por contribuir, igualmente, para a diminuição da impunidade no crime de assédio sexual.

\section{ASSÉDIO SEXUAL NA RELAÇÃO PROFESSOR-ALUNO}

Um dos tópicos mais controversos no crime de assédio sexual se refere à possibilidade de seu enquadramento na relação professor (a) aluno (a), estando divididas tanto a doutrina quanto a jurisprudência.

$$
\text { Prado (2006, p. 225) se }
$$
posiciona afirmativamente quanto à possibilidade de assédio sexual nesta relação, contrariamente a Bitencourt 
(2006, p. 43), que inadmite dita ocorrência.

Ishida (2009, p. 381) afirma que "há discussão se o professor comete, mas é explícita a sua ascendência”, dando por entender que a relação professor (a) aluno (a) constitui-se em hipótese de enquadramento no tipo.

A razão do conflito doutrinário e jurisprudencial repousa na interpretação a ser feita do artigo 216-A do Código Penal. Examina-se o texto: "Constranger alguém, com o intuito de obter vantagem ou favorecimento sexual, prevalecendo o agente de sua condição de superior hierárquico ou ascendência inerentes ao exercício de emprego, cargo ou função".

A interpretação mais adequada parece ser a de que o constrangimento incriminado na lei somente pode ocorrer no âmbito de uma relação de emprego, cargo ou função, entendida esta a que se estabelece entre o polo ativo assediador(a) e $\mathrm{o}$ polo passivo assediado(a), prevalecendo aquele(a) de sua condição de superioridade hierárquica ou ascendência. Assim, o assédio sexual não poderia ocorre na relação professor(a) - aluno(a), visto que, ainda que se reconheça naquele(a) superioridade hierárquica ou ascendência em relação ao aluno(a), dito constrangimento não ocorreria numa relação de emprego, cargo ou função entre eles, mas, tão somente, numa relação de docência. Em outras palavras, um(a) professor(a) pode, sob a ameaça de reprovar de ano o(a) estudante, valer-se de sua superioridade hierárquica para constrangê-lo(a) à prática de um ato sexual, mas jamais influenciar na perda do emprego, cargo ou função do(a) estudante, pois não há dita relação entre eles (polo ativo e passivo).

Por outro lado, o mesmo não ocorreria entre um(a) coordenador(a) de curso e o(a) professor(a), já que a não aquiescência às abordagens sexuais do coordenador(a) poderia repercutir de forma direta no emprego, cargo ou função daquele(a). Frise-se: o constrangimento incriminado em lei é aquele que se estabelece numa relação de superioridade hierárquica ou ascendência inerentes ao exercício de emprego, cargo ou função, compreendendo-se como tal uma relação de emprego, cargo ou função entre o polo ativo - assediador(a) e o polo passivo assediado(a).

Conclusão semelhante chega Andreucci (2008, p. 295), ao afirmar que 
só existe o crime de assédio sexual nas relações laborais, tendo sido vetado o parágrafo único do artigo 216-A CP, que tratava do assédio sexual nas relações familiares, domésticas, provenientes de coabitação, de hospitalidade e com abuso ou violação de dever inerente a ofício ou ministério.

$\mathrm{O}$ autor se refere à vedação do artigo 216-A, que dispunha:

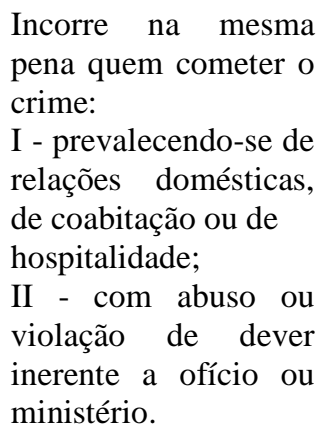

Do exame da redação do parágrafo vetado, depreende-se que $\mathrm{o}$ inciso II contemplava a figura do professor, que exerce, inegavelmente, um ofício ou ministério (o de ensinar). As razões do veto foram as seguintes:

$$
\begin{aligned}
& \text { No tocante ao } \\
& \text { parágraforánico } \\
& \text { projetado para o art. } \\
& \text { 216-A, cumpre } \\
& \text { observar que a norma } \\
& \text { que dele consta, ao } \\
& \text { sancionar com a } \\
& \text { mesma pena do caput } \\
& \text { o crime de assédio } \\
& \text { sexual cometido nas } \\
& \text { situações que } \\
& \text { descreve, implica }
\end{aligned}
$$

inegável quebra do sistema punitivo adotado pelo Código Penal, e indevido benefício que se institui em favor do agente ativo daquele delito. É que o art. 226 do Código Penal institui, de forma expressa, causas especiais de aumento de pena, aplicáveis genericamente a todos os crimes contra os costumes, dentre as quais constam as situações descritas nos incisos do parágrafo único projetado para o art. 216-A. Assim, no caso de o parágrafo único projetado vir a integrar $\mathrm{o}$ ordenamento jurídico, o assédio sexual praticado nas situações nele previstas não poderia receber o aumento de pena do art. 226, hipótese que evidentemente contraria $\mathrm{o}$ interesse público, em face da maior gravidade daquele delito, quando praticado por agente que se prevalece de relações domésticas, de coabitação ou de hospitalidade Estas, Senhor Presidente, as razões que me levaram a vetar o dispositivo acima mencionado do projeto em causa, as quais ora submeto à elevada apreciação dos Senhores 
Membros

Congresso Nacional ${ }^{25}$

Em ambas as hipóteses

revogadas (incisos I e II), o que procurou o legislador, com o veto, foi evitar que o agente do crime de assédio sexual fosse beneficiado com a impossibilidade de aumento da pena de $1 / 2$ (metade), no caso de ser o crime cometido nas condições estabelecidas pelo artigo 226 do Código Penal (que já abrangia as hipóteses previstas nos incisos vetados).

Em outras palavras, caso o legislador não houvesse vetado $\mathrm{o}$ mencionado dispositivo, não se poderia impor a referida causa de aumento, já que dita hipótese já estaria contemplada no próprio tipo, em flagrante benefício ao criminoso.

Não obstante, este veto acabou por excluir a possibilidade de enquadramento criminal não só do professor, mas de todos os que violem dever inerente a ofício ou ministério (desde, é claro, que não tenham relação de emprego, cargo ou função com a vítima), ainda que possuam superioridade hierárquica ou ascendência frente a ela.

\footnotetext{
${ }^{25}$ Mensagem $n^{\mathbf{0}}$ 424, de 15 de maio de 2001. Subchefia para Assuntos Jurídicos. Casa Civil. Presidência da República.
}

Entretanto, deve-se ressaltar que a conduta de um professor frente ao aluno, nas circunstâncias descritas, apesar de não caracterizar ilícito de natureza penal, pode constitui-se em ilícito de natureza civil, a autorizar a indenização por danos morais provocados pelo professor, bem como configurar eventual ilícito administrativo ${ }^{26}$, além de ser ato absolutamente censurável do ponto de vista moral, merecendo, por seu turno, as sanções devidas. Apenas não se deve, em nome das garantias penais e das liberdades individuais, forçar a criminalização da referida conduta quando ausente, de forma nítida, a materialidade do fato.

\section{PRINCÍPIOS CONSTITUCIONAIS PENAIS COMO LIMITE NEGATIVO À CRIMINALIZAÇÃO DE CONDUTAS}

\footnotetext{
${ }^{26}$ É possível que o assédio sexual possa ser considerado, conforme entendimento da Segunda Turma do STJ, improbidade administrativa, nos termos do art. 11 da Lei 8.429. A corte manifestou-se da seguinte forma: "Segundo o ministro, a jurisprudência do STJ considera imprescindível a existência de dolo para configurar atos de improbidade previstos no caput do artigo 11 da Lei 8.429 (ofensa a princípios da administração), e o dolo, no caso, foi reconhecido pelo tribunal estadual, que é soberano na análise das provas. $\mathrm{O}$ tribunal considerou contundente a prova trazida pelo testemunho das alunas." (http://www.tjrj.jus.br/documents/10136/1445158/ boletim-do-servico-de-difusao-77.pdf)
} 
Como todas as legislações do ordenamento brasileiro, as normas jurídicas encontram as suas limitações e justificações dentro do rol de princípios que foram estabelecidos pelo legislador constituinte na Carta Magna. Desta forma, a supressão da liberdade do indivíduo, viabilizada em sua expressão máxima pelos mecanismos repressivos do Direito Penal, deve respeitar os parâmetros negativos previstos em diversos incisos do art. $5^{\circ}$ da $\mathrm{CF} / 88$, nos denominados princípios constitucionais penais.

A força normativa da Constituição também é destacada por Queiroz (2008, p. 37), constituindo-se o fundamento de validade da ordem jurídica, encontrando-se as leis dispostas não num sistema desordenado de disposições, mas num sistema que se pretende lógico, coerente, e hierarquizado, cujas normas estão vinculadas à Constituição ${ }^{27}$.

\footnotetext{
27 Neste mister, para Queiroz, “os princípios exercem essencialmente uma dupla função: constitui um limite à intervenção do Estado (função de garantia) e é um instrumento de justificação dessa intervenção (função legitimadora), motivo pelo qual tanto serve à legitimação quanto à deslegitimação do sistema. QUEIROZ, Paulo. Direito penal: parte geral. 4. ed. Rio de Janeiro: Lumen Juris, 2008, p. 38.
}

O princípio da legalidade, também denominado princípio da reserva legal, está esculpido no inciso XXXIX do referido artigo e traz consigo o princípio segundo o qual não há crime sem lei anterior que o defina, nem pena sem prévia cominação legal. Essa norma constitucional encontra máxima expressão no Direito Penal por meio da construção histórica da figura do tipo penal $^{28}$. Este se afirmou como um instrumento revolucionário burguês, tendo sido um dos importantes avanços em direção ao positivismo jurídico, refreando, de um lado, os abusos do absolutismo e, por outro, afirmando uma nova ordem, protegendo a um só tempo o indivíduo perante $\mathrm{o}$ poder estatal e demarcando este mesmo poder como o espaço exclusivo da coerção penal." (BATISTA, 2007, p. 65)

Outro princípio de grande relevância é o da intervenção mínima, princípio este que não permite que o Direito Penal seja utilizado como a prima ratio na resolução de conflitos sociais.

\footnotetext{
28 Tipo é definido como Claus Roxin como a determinação legal, segundo o autor " [...] o termo é Gesetzesbestimmtheit, que sintetiza a exigência constitucional de que a lei, especialmente a penal, seja clara e determinada: nullum crimen sine lege certa. ROXIM, Claus. Política Criminal e sistema jurídico-penal. Tradução: Luís Greco. Rio de Janeiro: Renovar, 2002. p. 29.
} 
Este princípio, ao imprimir um caráter subsidiário ao Direito Penal, em relação a outras áreas do Direito, deslegitima a sua incidência quando outras instâncias (como o Direito Civil, Administrativo, Tributário, etc.) não puderem reger os conflitos, reforçando, destarte, a natureza fragmentária do Direito Penal.

A propósito do princípio da intervenção mínima, ensina Estefam (2010, p. 121) que este surgiu com a Declaração dos Direitos do Homem e do Cidadão, como modo de garantir que a intervenção estatal no plano individual se desse apenas quando estritamente necessário o que, não obstante, não tem impedido o legislador de promover uma verdadeira inflação legislativa, acabando por desacreditar o próprio sistema criminal.

Manifesta Andreucci (2008, p. 8) que do embate entre duas importantes ideologias modernas (movimento da lei e da ordem e movimento abolicionista), surgiu o princípio da intervenção mínima, pregando não se justificar a intervenção penal quando o ilícito possa ser eficazmente combatido por outros segmentos do Direito, atuando somente quando os demais ramos do Direito falharem (caráter de última ratio). Beccaria (2012, p. 17), a propósito, já se referia a este princípio ao afirmar que “[...] as penas que ultrapassam a necessidade de conservar o depósito da saúde pública são injustas por natureza."

O princípio da lesividade, por sua vez, impõe limites ao enquadramento jurídico-penal dos fatos, ao estabelecer, no inciso XXXV do artigo $5^{\circ}$ da $\mathrm{CF}$, que “a lei não excluirá da apreciação do Poder Judiciário lesão ou ameaça a Direito". A referida norma, ao mesmo tempo em que obriga o Estado a apurar as lesões e ameaças a direito, desautoriza o enquadramento e processamento criminal quando não houver direito lesado ou exposto a perigo de lesão.

O princípio constitucional penal da adequação social impede a punição de condutas que são aceitas socialmente. Corresponde a uma (necessária) adequação do Direito à realidade social, desautorizando a incriminação de fatos que não violam os valores médios de uma sociedade, buscando-se adequar o direito à realidade social ${ }^{29}$.

\footnotetext{
${ }^{29}$ Note-se que este fenômeno de adequação do Direito à realidade é visualizado não apenas no Direito Penal, mas primeiramente e em essência, no plano do próprio texto constitucional,
} 
Pelo princípio da insignificância, conhecido pelo brocardo latino minima non curat praetor (dos fatos mínimos não deve se ocupar o Estado-juiz), desautoriza a punição de condutas mínimas, correspondentes a lesões insignificantes ao bem jurídico.

Outro princípio constitucional penal de grande destaque é o da individualização da pena, previsto no art. $5^{\circ}$, XLVI da Constituição Federal, estabelecendo a disciplina das penas privativas de liberdade, a restrição de bens, a pena de multa, as prestações sociais alternativas e a suspensão ou interdição de direitos.

lembrando que este processo de mudança pode ser tanto de natureza formal quanto verificado pelo fenômeno da mutação constitucional. Com efeito, segundo esclarece Silva Neto: "É conquanto se presencie maior dificuldade para obter a constituição do que a lei ordinária, o que se vê, de fato, é a adequação dos textos constitucionais aos imperativos de natureza econômica, política, social, cultural e até antropológica. Em tais situações, veremos o aparecimento da figura do legislador constituinte derivado que exercerá a função de aproximar o texto da constituição ao contexto. Esse é o processo formal de mudança da constituição. E o mais conhecido; porém não é o único. Deveras, quando, sem se valer do referido processo formal de mudança, a constituição é modificada, estamos diante do fenômeno denominado mutação constitucional. SILVA NETO, Manoel Jorge. Curso de direito constitucional: atualizado até a EC n. 64, de 4 de fevereiro de 2010 e súmula vinculante n. 31 , de 17/02/2010. 6. ed. Rio de Janeiro: Lumen júris, 2010 , p. 24.
O princípio da limitação das penas, previsto no inciso seguinte, proíbe em nosso ordenamento as penas de morte (salvo em caso de guerra declarada, nos termos do art. 84, XIX), de caráter perpétuo, de trabalhos forçados, de banimento e as penas cruéis.

A proporcionalidade, como princípio do Direito Penal, fundamenta a necessidade de uma adequação entre a gravidade da lesão ou perigo de lesão a bem jurídico e a gravidade da sanção atribuída pela lei. Em um primeiro momento, o princípio da proporcionalidade impõe um dever de que sejam observados pelo legislador os limites da necessidade de se tipificar a conduta, a adequação da punição ao bem jurídico que se pretende proteger e, por fim, a observância da proporcionalidade em sentido estrito.

Não se pode olvidar a menção a outros princípios constitucionais penais, como a intranscendência (art. $5^{\mathbf{0}}, \mathrm{XLV}$ $\mathrm{CF}$ ), segundo o qual a pena não deve passar da pessoa do criminoso; a culpabilidade, a fundamentar a responsabilidade subjetiva no Direito Penal (responsabilização em virtude de atuação dolosa ou culposa); extra 
atividade da lei penal (a garantir a irretroatividade da lei penal, exceto para beneficiar o réu), dentre outros.

Para Prado, apesar de a Constituição irradiar a sua força normativa para todo o ordenamento jurídico, apresenta particular e definitiva influência no Direito Penal, já que cabe a ele a proteção dos bens e valores essenciais ao desenvolvimento do indivíduo em sociedade, encontrando na Magna Carta as raízes materiais dos bens jurídico-penais tutelados ${ }^{30}$.

Dá-se, no entanto, especial relevo ao princípio contido no art. $1^{\circ}$, inciso III, da $\mathrm{CF} / 88$ : o princípio da dignidade da pessoa humana. Entendemos que tal princípio também figura como uma limitação negativa à atuação do Direito Penal na regulação das condutas sociais, na medida em que a intervenção penal só é autorizada quando não existem outros meios para se defender o bem jurídico protegido. Mesmo que se possa argumentar que a dignidade da pessoa humana está envolvida também no âmbito

30 De acordo com Prado, "é fundamental, inclusive para a salvaguarda dos direitos fundamentais, que a interpretação e aplicação da lei penal seja feita sempre conforme a Constituição e os ditames do Estado Democrático de Direito. PRADO, 2008, p. 58. da pessoa assediada, verifica-se que a proteção desta interferência já acontecia de modo suficiente no âmbito trabalhista, civil e administrativo, sendo uma extrapolação do princípio da proporcionalidade por parte do legislador na tipificação do assédio sexual.

Os princípios constitucionais servem, como ensina Greco (2006, p. 67), de obstáculo a ser transposto pelo legislador no momento de inovação do ordenamento jurídico, pela criação ou revogação dos tipos penais, tendo como fundamento o parágrafo único do artigo $1^{\circ}$ da Constituição, a ilustrar a natureza e força do Poder Constituinte Originário, em que "todo poder emana do povo".

Segundo Greco, no que concerne à tarefa legiferante, há uma busca, na elaboração de leis, em selecionarem-se os bens fundamentais a serem protegidos em uma sociedade. Contudo, mesmo sendo a opção racional de nossa sociedade o Direito Penal Mínimo, nem sempre os clamores sociais diante de fatos mais bárbaros permitem que este seja, de fato, o caminho seguido. De acordo com o referido autor, em decorrência de pressões da sociedade, cria-se "[...] um terrível processo de inflação legislativa, que 
somente conduz ao descrédito e à desmoralização do Direito Penal." (GRECO, 2006, p. 72-73)

Vale lembrar, por oportuno, que a tutela constitucional também contempla princípios de abrangência processual penal, como o devido processo legal, o contraditório e a ampla defesa, a vedação a provas ilícitas, dentre outras. Neste âmbito, Ishida (2009, p. 6) confere ao Direito Constitucional o papel de ramo do Direito estabelecedor dos princípios de base à jurisdição penal, como o direito de ação, a ampla defesa, o contraditório e o juiz natural.

Esta é a natureza do processo penal, que não pode ser compreendido, na visão de Lopes Jr. (2008, p. 9), como um simples instrumento a serviço do poder punitivo, mas sim como instrumento limitador do poder e garantidor do indivíduo, devendo-se desvencilhar a ideia de impunidade do respeito às garantias fundamentais.

O processo penal passa, igualmente, pela necessária observância das garantias constitucionais, o que leva Oliveira (2009, p. 30) a afirmar que não haverá, no âmbito da dogmática penal, compatibilidade entre o garantismo e a intervenção penal, quando se puder justificar a condenação criminal pela estrita observância do devido processo penal constitucional.

A criminalização da figura do assédio sexual situa-se, pois, na contramão de uma tendência descriminalizadora do Direito Penal, ademais ter surgido à revelia dos princípios constitucionais penais aqui já mencionados. Com efeito, na medida em que faz incidir a sua proteção no âmbito das relações já tuteladas por outras áreas do Direito, constata-se a inobservância do legislador ao princípio da intervenção mínima.

Igualmente, por ter-se estabelecido no crime de assédio sexual pena privativa de liberdade, semelhantemente ao que ocorre com outros crimes de natureza sexual onde há o emprego de força física ou grave ameaça (a exemplo do estupro), considera-se igualmente incompatível a norma prevista no art. 216-A do CP com o princípio da proporcionalidade.

Semelhante crítica pode ser feita no tocante ao princípio da insignificância (mínima non curat praetor), já que, factualmente, pode o empregado elevar 
um simples comentário dúbio ou jocoso à condição de constrangimento de natureza sexual, invocando o aparato administrativo-judicial para o processamento do seu empregador. Melhor seria, como já se frisou, deixar a regulação destas hipóteses, tão corriqueiras em um ambiente de trabalho, para a tutela de outras instâncias do Direito, como o próprio Direito do Trabalho.

Nota-se, também, a infelicidade do legislador na não observância do princípio da adequação social, segundo o qual não se deve punir os fatos que são aceitos socialmente, o que pode vir a gerar injustiças, na medida em que constatamos, hodiernamente, práticas mais abertas e flexíveis em um ambiente de trabalho, a engendrar certos comportamentos, brincadeiras e licensiosidades, que, a depender do caso, podem vir a ser interpretadas como assédio.

A nosso ver, resta ausente de legitimidade e materialidade o referido tipo, na medida em que não se adéqua aos princípios constitucionais penais da intervenção mínima, proporcionalidade, insignificância e adequação social, urgindo, por parte do aplicador, uma interpretação mais restritiva do alcance da norma, a fim de contextualizá-la, no caso concreto, à realidade brasileira e ao plano das relações socialmente aceitas em um ambiente de trabalho.

\section{CONCLUSÃO}

O critério de escolha dos tipos penais deve repousar na Constituição, servindo a Magna Carta como guia para o legislador na instituição de novas figuras típicas em nosso ordenamento, bem como na eventual modificação dos tipos já existentes, criando-se limites para a imposição da pena ao caso concreto com base em princípios constitucionalmente previstos.

A criminalização de novas condutas passa, outrossim, pela escolha da sociedade de qual caminho prefere trilhar: o do direito penal mínimo (com o consagração da fragmentariedade $\mathrm{e}$ subsidiariedade do Direito Penal, garantidor dos direitos e liberdades fundamentais) ou do direito penal máximo (com sua lógica impregnadamente punitiva e suas ilusões 
e falsas esperanças de solução dos problemas de ordem social).

No que se refere ao tipo de assédio sexual, vê-se que a escolha de criminalização do citado tipo repousou muito mais num apelo da mídia e de parte da sociedade do que, propriamente, numa decisão racional e reflexiva de política criminal. Ademais, a salvaguarda dos bens jurídicos envolvidos na conduta do assédio sexual poderia ser feita por normas penais incriminadoras já existentes, a exemplo dos crimes contra a honra ou, mais acertadamente, dos crimes de ameaça ou constrangimento ilegal, nos casos mais gravosos em que fosse realmente necessária a intervenção do Direito Penal.

A criminalização da figura do assédio sexual revela-se, pois, mais um anacronismo do nosso legislador, insensível, inclusive, à verificação factual de que o nosso próprio temperamento latino, refletido na frouxidão de rigores formais (mesmo num ambiente de trabalho), acabaria por engendrar um conflito entre o programa da norma e o seu contexto social.

Trata-se o crime de assédio sexual de modalidade de crime próprio, podendo ser cometido apenas por pessoa dentro da condição de superioridade hierárquica ou ascendência inerente ao exercício de cargo, emprego ou função, desde que comprovado o inequívoco dissentimento da vítima às investidas e cantadas do assediador. É de natureza formal, instantâneo, plurissubsistente e cuja tentativa, embora de difícil visualização, é admitida, tutelando-se, a nosso ver, a dignidade sexual do(a) empregado(a).

No que se refere à ação penal, entende-se que a mudança engendrada pela lei 12.015/09 promoveu um significativo avanço ao acabar com a ação penal privada, extinguindo a hipótese de perdão da vítima, bem como retirando a necessidade de que a vítima tenha que buscar um advogado ou defensor público para intentar a ação penal, o que vem a contribuir, prima facie, para a diminuição da impunidade no crime de assédio.

Este, por sua natureza pluriofensiva, engendra consequências jurídicas não apenas no Direito Penal, mas também no Direito Administrativo (caso a relação entre assediador(a) e assediado(a) seja de cargo ou função pública), e, sobretudo, de natureza 
trabalhista, o que se revela evidente pela própria especificidade desta área do Direito, suscitando, em caso de configuração do crime de assédio, não apenas o pagamento das verbas rescisórias, dada a insustentabilidade do vínculo laboral, mas também a indenização por danos morais eventualmente sofridos pelo(a) empregado(a), a cargo da Justiça do Trabalho, ou mesmo por meio da Ação Civil ex delicto.

Não obstante, resta ausente de legitimidade e materialidade o referido tipo, na medida em que não se adéqua aos princípios constitucionais-penais da intervenção mínima, proporcionalidade, insignificância e adequação social, urgindo, por parte do aplicador da lei, uma interpretação mais restritiva do alcance da norma, a fim de contextualizála, no caso concreto, à realidade brasileira.

\section{REFERÊNCIAS}

ANDREUCCI, Ricardo Antônio. Manual de direito penal. 4. ed. São Paulo: Saraiva, 2008.

BATISTA, Nilo. Introdução critica ao direito penal brasileiro. $11 \mathrm{ed}$. Rio de Janeiro: Revan, 2007.
BECCARIA, Cesare. Dos delitos e das penas. 3. ed. São Paulo: CL EDIJUR, 2012.

BITENCOURT, Cezar Roberto. Tratado de direito penal. $v$. 4: parte especial. 3 . ed. São Paulo: Saraiva, 2008.

BOULOC, Bernard; LEVASSEUR, Georges; STEFANI, Gaston. Droit pénal général. 14. ed. Paris: Dalloz, 1992.

BRANDÃO, Cláudio. Curso de direito penal: parte geral. Rio de Janeiro: Forense, 2008.

BRENTS, Barbara G.; SANDERS, Teela. Mainstreaming the sex industry: economic inclusion and social ambivalence. In: Regulating sex/work: from crime control to neo-liberalism? In: Journal of law and society. v. 37. Cardiff, Reino Unido: Wiley-Blackwell, 2010.

CAMARA, Edson de Arruda. Assédio sexual: um problema trabalhista, penal ou cível? In: Revista TRT 6 Região. V. 10, n. 26, ago/dez, 1998.

CASSAR, Vólia Bonfim. Direito do trabalho. 2. ed. Niterói: Impetus, 2008.

CAIRO JÚNIOR, José. Direito do trabalho. V. 1. Salvador: Juspodium, 2006.

CAPEZ, Fernando. Curso de direito penal: parte geral (arts. $1^{\circ}$ ao 120 ). 9. ed. São Paulo: Saraiva, 2005.

CARNEIRO, Yuri. O Novo delito de assédio sexual: a necessidade de uma análise crítica em face do direito penal moderno. In: Revista dos mestrandos em Direito da UFBA: estudos em homenagem ao Profesor Josaphat Marinho. Jan-Dez 2001. 
CHAVANNE, A.; LESASSEUR, G. Droit pénal et procédure pénale. 2. ed. Paris: Sirey, 1971.

DAMIAN, Sérgio A. S.; OLIVEIRA, Joabet T. de. Assédio sexual: dano e indenização. São Paulo: Edijur, 1999.

DELGADO, Maurício Godinho. Curso de direito do trabalho. 7. ed. São Paulo: LTr, 2008.

DESCARTES, René. As paixões da alma. Trad. Ciro Mioranza. São Paulo: Escala, 2006.

ESTEFAM, André. Direito penal: parte geral. São Paulo: Saraiva, 2010.

GARCIA, José Ángel Brandariz. Política criminal de la exclusión: el sistema penal en tiempos de declive del estado social y de crisis del estado-nación. Granada: Comares, 2007.

GOMES, Orlando; GOTTSCHALK, Elson. Curso de direito do trabalho. 18. ed. Rio de Janeiro: Forense, 2008.

GRECO, Rogério. Direito penal do equilíbrio: uma visão minimalista do direito penal. 2. ed. Niterói, RJ: Impetus, 2006.

HERRERO, César Herrero. Política criminal integradora. Madrid: Dykinson, S. L., 2007.

HULSMAN, Louk; CELLIS, Jaqueline Bernat de. Penas perdidas: o sistema penal em questão. Trad. Maria Lúcia Karan. Niterói: LUAM, 1993.

ISHIDA, Válter Kenji. Curso de direito penal. São Paulo: Atlas, 2009.
Processo penal: de acordo com a reforma processual penal. São Paulo: Atlas, 2009.

LOPES JR. Auri. Direito processual penal: e sua conformidade constitucional, v.1. 3. ed. Rio de Janeiro: Lumen Juris, 2008.

MARTINS, Sérgio Pinto. Direito do trabalho. 25. ed. São Paulo: Atlas, 2009.

MIRABETE, Júlio Fabbrini. Manual de direito penal, v. 2: parte especial: arts. 121 a 234-B do CP. 27. ed. São Paulo: Atlas, 2010.

MUÑOZ CONDE, Francisco. Teoría general del delito. 3. ed. Vanencia: tirant lo blanch, 2004.

NASCIMENTO, Amauri Mascaro. Curso de direito do trabalho: história e teoria geral do direito do trabalho: relações individuais e coletivas do trabalho. 24. ed. São Paulo: Saraiva, 2009.

NUCCI, Guilherme de Souza. Código penal comentado. 8. ed. São Paulo: Revista dos Tribunais, 2008.

OLIVEIRA, Eugênio Pacelli. Curso de processo penal. 12. ed. Rio de Janeiro: Lumen Juris, 2009.

ORTEGA Y GASSET, José. O Homem e a gente: inter-comunicação humana. Trad. J. Carlos Lisboa. 2. ed. Rio de Janeiro: Livro Ibero-Americano, 1973.

PRADO, Luiz Régis. Curso de direito penal brasileiro: parte geral: arts. $1^{\circ}$ a 120. 8. ed. São Paulo: Revista dos Tribunais, 2008. 
Curso de direito penal

brasileiro: parte especial, v.3. 4. ed. São Paulo: Revista dos Tribunais, 2006.

QUEIROZ, Paulo. Direito penal: parte geral. 4. ed. Rio de Janeiro: Lumen Juris, 2008.

ROXIN, Claus. Estudos de direito penal. Trad. Luís Greco. Rio de Janeiro: Renovar, 2006.

, Clauss. Política criminal e sistema jurídico-penal. Trad. Luís Greco. Rio de Janeiro: Renovar, 2002.

SANTOS, Aloysio. Assédio sexual nas relações trabalhistas e estatutárias. Rio de Janeiro: Forense, 1999.

SILVA NETO, Manoel Jorge. Curso de direito constitucional: atualizado até a EC n. 64, de 4 de fevereiro de 2010 e súmula vinculante n. 31, de 17/02/2010. 6. ed. Rio de Janeiro: Lumen júris, 2010. sexual. In: JESUS, Damásio E.; GOMES, Luiz Flávio. Assédio sexual. São Paulo: Saraviva, 2002.

SOUTO, Miguel Abel. Teorias de la pena y limites al ius punieni desde el estado democrático. Madrid: Dilex, S. L., 2006.

WILDE, Oscar. A alma do homem sob o socialismo. Trad. Heitor Ferreira da Costa. Porto Alegre: L\&M, 2003. 